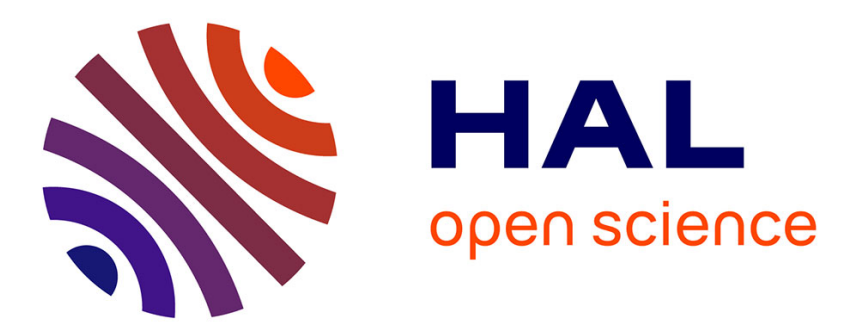

\title{
Toward an operational tool to simulate green roof hydrological impact at the basin scale: a new version of the distributed rainfall-runoff model Multi-Hydro
}

Pierre-Antoine Versini, Auguste Gires, Ioulia Tchiguirinskaia, D Schertzer

\section{- To cite this version:}

Pierre-Antoine Versini, Auguste Gires, Ioulia Tchiguirinskaia, D Schertzer. Toward an operational tool to simulate green roof hydrological impact at the basin scale: a new version of the distributed rainfall-runoff model Multi-Hydro. Water Science and Technology, 2016, 74 (8), pp.1845 - 1854. 10.2166/wst.2016.310 . hal-01635682

\section{HAL Id: hal-01635682 https://hal.science/hal-01635682}

Submitted on 15 Nov 2017

HAL is a multi-disciplinary open access archive for the deposit and dissemination of scientific research documents, whether they are published or not. The documents may come from teaching and research institutions in France or abroad, or from public or private research centers.
L'archive ouverte pluridisciplinaire HAL, est destinée au dépôt et à la diffusion de documents scientifiques de niveau recherche, publiés ou non, émanant des établissements d'enseignement et de recherche français ou étrangers, des laboratoires publics ou privés. 


\title{
Toward an operational tool to simulate green roof hydrological impact at the basin scale: a new version of the distributed rainfall-runoff model \\ Multi-Hydro
}

\author{
Pierre-Antoine Versini ${ }^{\mathrm{a}}{ }^{,}$, Auguste Gires ${ }^{\mathrm{a}}$, Ioulia Tchinguirinskaia ${ }^{\mathrm{a}}$ and Daniel Schertzer ${ }^{\mathrm{a}}$ \\ ${ }^{a}$ HMCo, Ecole des Ponts, UPE, Champs-sur-Marne, FRANCE \\ *Corresponding author. E-mail: pierre-antoine.versini@enpc.fr
}

Published in Water Science and Technology (2016)

\begin{abstract}
Currently widespread in new urban projects, green roofs have shown a positive impact on urban runoff at the building scale: decrease and slow-down of the peak discharge, and decrease of runoff volume. The present work aims to study their possible impact at the catchment scale, more compatible with stormwater management issues. For this purpose, a specific module dedicated to simulate the hydrological behaviour of green roof has been developed in the distributed rainfall-runoff model (Multi-Hydro). It has been applied on a French urban catchment where most of the buildings roofs are flat and assumed to accept the implementation of green roof. Catchment responses to several rainfall events covering a wide range of meteorological situation have been simulated. The simulation results show green roof can significantly reduce runoff volume and the magnitude of peak discharge (up to $80 \%$ ) depending on the rainfall event and initial saturation of the substrate. Additional tests have been made to assess the susceptibility of this response regarding both spatial distributions of green roofs and precipitation. It appears that the total area of greened roofs is more important than their locations. On the other hand, peak discharge reduction seems to be clearly dependent of spatial distribution of precipitation.
\end{abstract}

\section{1-INTRODUCTION}

Green roofs have become relatively commonplace over the last 20 years in urban areas for many reasons. They may contribute to enhance the aesthetic value of buildings, but also to reduce heat island through increasing evapotranspiration, to improve the quality of the air, to protect biodiversity and to manage urban runoff (Berndtsson, 2010). Their use in urban runoff management is surely the most significant argument used to promote their implementation because the best known and studied. Most of the previous studies were focused on the hydrological impact of green roofs at the building scale where these impacts initially occur: Stovin et al. (2012); Locatelli et al. (2014); Yilmaz et al. (2016). These works usually present the results provided by an experimental green roof instrumented to collect continuous runoff and precipitation data. From such experimentals, the main performance of green roofs in quantitative management of storm water is known to be: (i) the reduction of runoff volume at the annual scale, and (ii) the peak attenuation and delay at the rainfall event, although a subject to the green roof structure, rainfall intensity and antecedent soil moisture conditions (see Simmons et al., 2008). The monitored sites were also often used to develop some specific models able to simulate the hydrological behaviour of the observed green roofs during the selected rainfall events. Two types of model have been tested: conceptual based on a reservoir structure (see Versini et al., 2015a, Stovin et al. 2013 for instance) and physically 
based using Richards' law (Hilten et al., 2008, Palla et al., 2009). The former uses calibrated parameters to reproduce correctly a specific green roof's behavior, whereas the latter is based on physical properties (such as hydraulic conductivity for instance) that could be numerous and non homogenous in space and time. Moreover, the physically based models were usually applied only at the roof scale, mainly due to the question of space-time resolution, the evolved with scale environmental complexity and resulting computational costs.

Despite the current spread of green roofs, a few works have been published on their impacts on stormwater runoff to solve urban management issues at the catchment scale. Most of them use the semi-distributed SWMM model (Rossman, 2004) to reproduce the hydrological response of an urban watershed. Hence, green roofs have been represented as the percentage of each of the sub-catchment areas. Different procedures were tested to simulate the green roof behaviour in SWMM. Palla (2008) used the Soil Conservative Service (SCS) Curve Number as infiltration model in an aquifer system as thick as the substrate depth. Applied on a 5.5 ha urban catchment, the impacts of several green roofing scenarios were assessed. More simply, Carter and Jackson (2007) used the SCS method as infiltration and runoff model to simulate green roof response on the corresponding area. Using synthetic precipitation events, they evaluated the impact of a widespread green roof application in an urban watershed (237 ha). Versini et al. (2015a, 2015b) developed and integrated a reservoirs based model into SWMM to simulate green roof behaviour. It was applied on two urban catchments (respectively 550 and 240 ha) to assess the impact of green roofs on Combined Sewage Overflow (CSO) and flooding issues.

In spite of all this progress, the continuous simulation of a green roof functioning still remains an ultimate challenge for the operational use, independently of the scale of application. While this challenge is beyond the scope of the paper, the proposed integration of a conceptual green roof module into a fully distributed rainfall-runoff model expands the current state of the art. Indeed, this is the first study of hydrological impacts of green roofs regarding the spatial distribution of precipitation during several rainfall events by using a fully distributed model implemented on a real urban catchment. The suggested hybridisation constitutes an important step towards an operational tool because, from one side, its distributed structure allows to take into account: (i) the spatial variability of land use and therefore of green roofs' locations w.r.t. storm water networks, (ii) the evolving dynamics due to the layout of impervious and pervious surfaces, (iii) the general complexity of urban environments, and (iv) the spatial distribution of precipitation and of other involved hydrological processes. From the other side, while preserving the main features, the use of conceptualisation helps to significantly reduce the computation time that is very important in regard to the operational use. As will be shown below, the distributed structure of the hybridised system is well adapted to study the influence of spatial distribution of green roofs into the studied catchment,

\section{2-MODEL DESCRIPTION}

\section{2-1 The Multi-Hydro platform and the Green Roof module}

The Multi-Hydro distributed rainfall-runoff model is being developed at the Ecole des Ponts ParisTech (https://hmco.enpc.fr/Tools/Multi-Hydro). It is a numerical platform that makes several models interact, each of them representing a specific portion of the water cycle in an urban environment: surface runoff and infiltration TREX (Velleux et al., 2011) depending on a land use classification (roads, houses, gullies, green spaces, water bodies are differentiated), 
subsurface processes VS2DT (Mills and Healy, 1993) and sewer network drainage SWMM (Rossman, 2004) representing the layout of conduits and nodes. During last years MultiHydro has undergone numerous improvements enabling to move from the initially simple cascade of models (El Tabach et al., 2009) to a more complex, often retroactive, interplay between them (Giangola-Murzyn, 2014). In particular, return flow releases to the surface are used to recover the evapotranspiration effects and soil moisture conditions between storms, allowing to re-initiate the Green-Ampt parameters within multi-event simulations. Thus, Multi-Hydro stands now as a decision support tool to evaluate a large number of scenarios showing the impact of local changes at different scales.

Special care was given to the coupling between each module to allow users to choose the modeling chain configuration according to their needs. Hence, the interactions between the surface module and either subsurface domain or sewer network could be deactivated. Following Gires et al. (2014), in this paper only the interactions between the stormwater sewer system and surface flow have been considered. They are handled through the gullies where water can flow in both directions.

A specific module dedicated to simulate green roof behaviour has been added in MultiHydro. Integrated among "resilience infrastructure" Multi-Hydro options (already comprising basin and barrier), this module is applied on each cell previously identified as green roof. Based on a reservoir structure (as the model presented in details in Versini et al. (2015a)), it assumes: (i) the water content is constant with depth, and (ii) hydraulic conductivity is constant (and not a function of water content) in the substrate. It produces for each time step $\Delta t$ a modified rainfall field representing the green roof response for green roof cells and conserving the original rainfall for the remaining cells. These new rainfall fields are then used as input data for the complete Multi-Hydro cycle. Within these loops, green roof cells are considered as standard roof; i.e. impervious pixels whose water is directly routed to the nearest gully.

In details, the reservoir level fluctuation is conducted by a simple in/out relationship:

$$
H_{-} \text {res }(t+\Delta t)=H_{-} \text {res }(t)+P(t)-Q o u t(t)
$$

Where $H_{-}$res $(t)$ is the reservoir level, $P(t)$ represents precipitation rate and Qout $(t)$ the green roof contribution to runoff at time $t$, all expressed in $\mathrm{mm}$.

Green roof contribution is conducted by the following equation depending on several physical parameters: Thick (substrate thickness or depth, mm), Ksat (saturated hydraulic conductivity, $\mathrm{mm} / \mathrm{s}$ ), and $F C$ (field capacity) that have to be adjusted:

$$
\text { Qout }(t)=\max \left[\frac{\text { Ksat } \times \Delta t}{\text { Thick }} \times\left(H_{-} \text {res }(t)-F C \times \text { Thick }\right), 0\right]
$$

Initial water level is introduced at the beginning of the simulation:

$$
H_{-} \text {res }(0)=\text { Thick } \times \text { Por } \times \text { Init }
$$

Where Por is the porosity and Init the initial state of substrate saturation.

Similar to other types of surface, green roof runoff is then routed by using the Manning relationship depending on a roughness coefficient (roug). With disconnected subsurface module, the evapotranspiration process is no longer represented, and Multi-Hydro is adapted to work at the rainfall event scale for sizing applications and impact studies. Through the Init 
parameter, initial losses are considered as model input. The green roof module is also more suited to represent the detention process than the retention one. From an operational point of view, the Init parameter can be modified to produce optimistic/pessimistic scenarios.

A validation of such 'event-adapted' version of Multi-Hydro after the green roof module integration is necessary to demonstrate the compatibility of two models, the overall functioning of their system and its sensitivity to the initial conditions. Use of the full version of Multi-Hydro is beyond the scope of this paper, because the multi-event soil moisture conditions generated by Multi-Hydro are not directly applied to the pixels containing green roofs, their interrelations are subject to further research.

\section{2-2 Validation of the Green roof module}

To ensure its validity, Multi-Hydro and its green roof module was implemented and tested to represent the hydrological response of a monitored experimental green roof located in Trappes (20 km from Paris, France) and supported by the CEREMA. This green roof $\left(35 \mathrm{~m}^{2}\right)$ combines an extensive vegetation layer made with a mix of Sedum species, a $3 \mathrm{~cm}$ substrate with lapillus, peat and green compost, a filter layer and a drainage layer. Rainfall and discharge were continuously monitored from June 2011 to August 2012 (more details in Gromaire et al., 2013). Green roof characteristics have been provided by manufacturers (Por $=0.5$ ) or estimated by previous works (Versini et al., 2015a, b): $F C=0.4, K s a t=1200 \mathrm{~mm} / \mathrm{h}$, and roug $=0.5$. Note that although adjusted parameters are related to physical characteristics of green roof, they may differ from the theoretical values.

\begin{tabular}{lcccc}
\hline & Rainfall $(\mathrm{mm})$ & Rainfall duration $(\mathrm{h})$ & Nash & Init $(\%)$ \\
\hline $03 / 11 / 2011$ & 21.5 & 5.50 & 0.86 & 50 \\
$04 / 12 / 2011$ & 8 & 1.66 & 0.82 & 50 \\
$07 / 06 / 2012$ & 9 & 2.00 & 0.90 & 20 \\
$18 / 06 / 2012$ & 20 & 2.00 & 0.91 & 10 \\
$21 / 06 / 2012$ & 8 & 0.50 & 0.91 & 40 \\
\hline
\end{tabular}

Table 1. Validation of the Multi-Hydro green roof module for the 5 main rainfall events of the monitoring period.

The Multi-Hydro green roof module was successfully validated for the five main rainfall events that occurred during the monitoring period. Several values of Init (ranging 10 to 90\%) were tested. Selected values are reported in Table 1, which synthesizes the results. Simulations and observations matched very well (Nash criterion is always higher than 0.8). Initial saturation appears as a key factor conducting the beginning of the hydrological response (especially for small rainfall events). A maximum value of $50 \%$ was found, meaning that a higher saturation of the substrate can hardly be reached after a dry period. Figure 1 illustrates the resulting simulations for the two main events (one during the wet period and one during the dry one). It also appears that the substrate is relatively saturated in winter (around 50\%), whereas it is dryer in summer (close to 10\%). Note that at the beginning of the last event (21/06/2012), the substrate was saturated about $40 \%$ because it rained $40 \mathrm{~mm}$ during the previous week. 

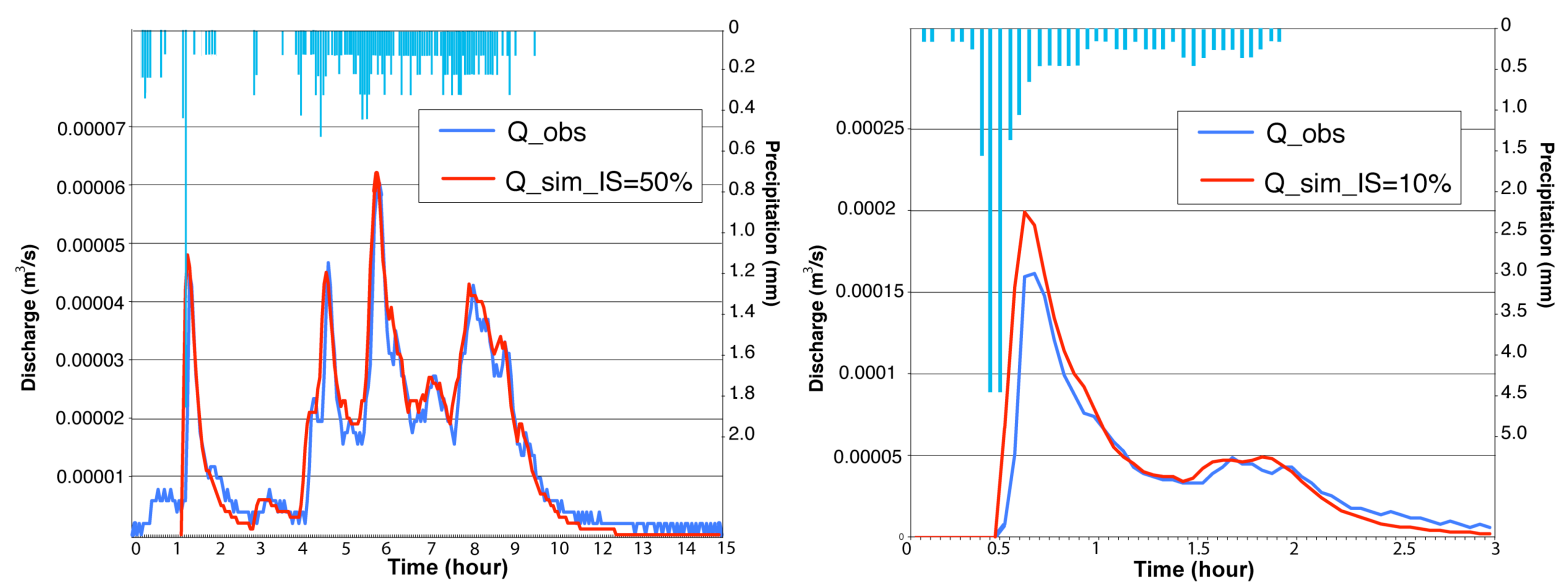

Figure 1. Comparison between observed and simulated discharge for the Trappes green roof: $03 / 11 / 2011$ event on the left and 18/06/2012 event on the right

\section{3- CASE STUDY}

\section{3-1 Presentation of the Loup catchment}

A 65 ha test-catchment, called Loup, has been selected in a highly populated and urbanized city (Villepinte, France). Figure 2 displays its representation with pixels of size $10 \mathrm{~m} \times 10 \mathrm{~m}$ inputted into the Multi-Hydro model. Regarding land cover data, the catchment is covered by more than $38 \%$ of building. The remaining surface is essentially covered by roads and parking lots (named as "other" in Fig 2), making the catchment highly impervious (close to $90 \%$ ). Most of the buildings are devoted to industrial activities. The corresponding roof area represents more than $34 \%$ of the catchment area $(16.7 \mathrm{ha})$. For the rest of the study, it has been assumed that these building roofs are flat and that the implementation of a small and light green roof (that used for the green roof module validation) is technically possible. Their corresponding area in the studied catchment is called "green roofing potential".

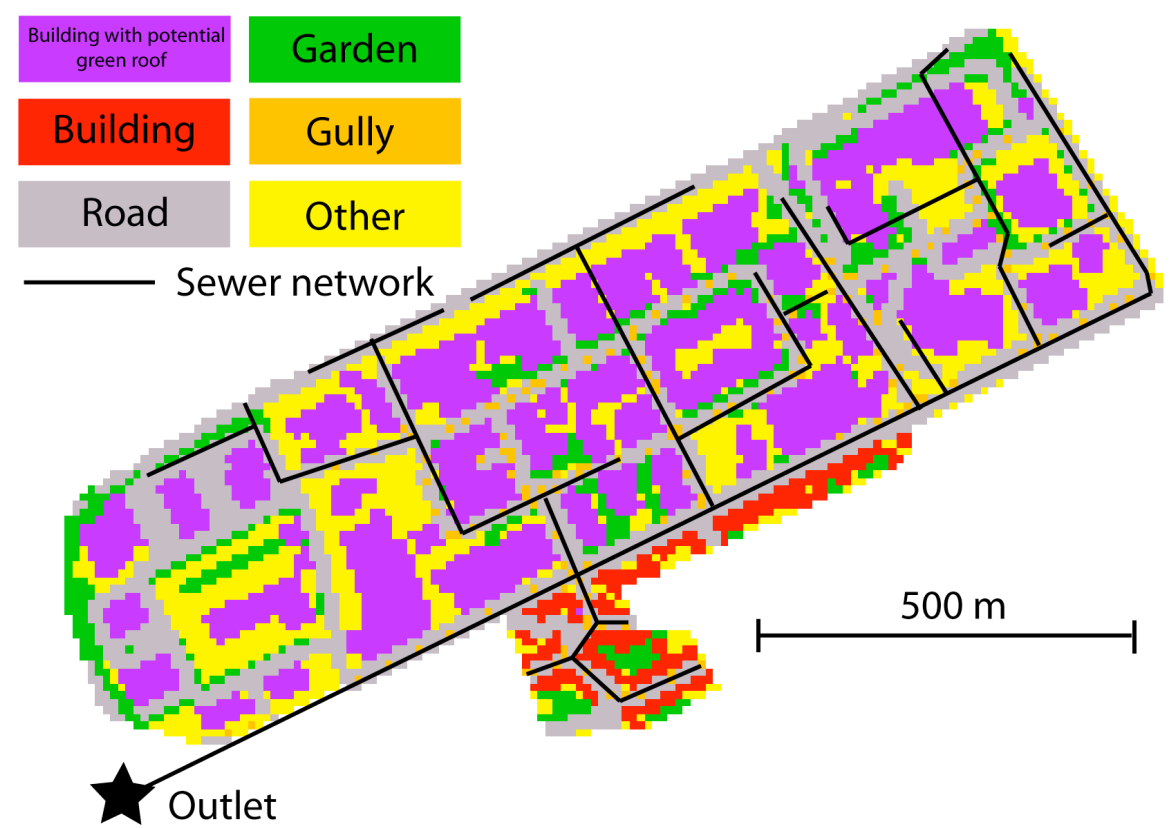

Figure 2. Loup catchment: land use spatial distribution with pixel of size $10 \mathrm{~m}$ x $10 \mathrm{~m}$, and sewer network inputted on Multi-Hydro 
Discharge data are deduced from a monitored storage catchment located at the outlet. Using this data on four rainfall events, Multi-Hydro implemented with the same $10 \mathrm{~m}$ resolution was previously validated on the Loup catchment (see Gires et al., 2014). The data (topography, landuse, sewer network) was formatted for Multi-Hydro from commonly available GIS data with the help of an in-house developed tool called MH AssimTool (Giangola-Murzyn, 2014).

\section{3-2 Rainfall inputs}

On the one hand, rain gauge (5-minute resolution) data covering 2010-2012 was provided by the Water Direction of the Seine-Saint-Denis County. From this database, 16 rainfall events have been extracted. These events differ by their characteristics in terms of rainfall accumulation (from 6 to $40.6 \mathrm{~mm}$ ) and rainfall duration (from 0.5 to 8.2 hours). Corresponding return periods vary between one month to more than five years (see Table 2 for more details).

On the other hand, radar data was also provided by Météo France. They are characterized by a resolution of $1 \mathrm{~km}$ in space and 5 minutes in time. Radar data were collected for the event of 9 February 2009. On the studied catchment, the corresponding total rainfall depth is 8.3 $\mathrm{mm}$ for a duration of approximately $6 \mathrm{~h}$. This event is considered as common (return period of one month) and has been chosen because green roof performance is better evaluated based on common events than on extreme ones (as already mentioned in Carson et al., 2013, Fassman-Beck et al., 2013 or Versini et al., 2015a). Based on these radar rainfall fields, an ensemble of 50 realistic downscaled rainfall fields with a resolution of $10 \mathrm{~m}$ in space has been generated. The rainfall input downscaling technique relies on the framework of Universal Multifractals (Schertzer and Lovejoy, 1987), which has been extensively used (Schertzer and Lovejoy, 2011 for a recent review) to analyse and simulate geophysical fields extremely variable over wide ranges of scales. More details on the downscaling process can be found in Gires et al. (2012).

\begin{tabular}{ccccc}
\hline Date & $\begin{array}{c}\text { Rainfall } \\
(\mathrm{mm})\end{array}$ & $\begin{array}{c}\text { Duration } \\
(\mathrm{h})\end{array}$ & $\begin{array}{c}\text { Return } \\
\text { period }\end{array}$ & $\begin{array}{c}\text { Peak value } \\
\left(\mathrm{m}^{3} / \mathrm{s}\right)\end{array}$ \\
\hline $14 / 07 / 2010$ & 40.60 & 5.17 & $5<<10 \mathrm{yrs}$ & 3.32 \\
$12 / 07 / 2010$ & 32.60 & 2.40 & $2<<5$ yrs & 3.16 \\
$12 / 06 / 2010$ & 26.40 & 2.33 & 2 years & 2.39 \\
$05 / 06 / 2011$ & 21.00 & 2.00 & 2 years & 2.88 \\
$03 / 06 / 2012$ & 23.20 & 3.75 & 1 year & 2.63 \\
$26 / 08 / 2011$ & 23.00 & 4.00 & 1 year & 1.57 \\
$21 / 06 / 2012$ & 15.60 & 0.92 & 1 year & 2.57 \\
$19 / 05 / 2012$ & 13.20 & 1.40 & 6 months & 1.81 \\
$03 / 11 / 2012$ & 15.60 & 7.00 & 6 months & 1.64 \\
$22 / 07 / 2011$ & 8.80 & 2.00 & 6 months & 1.20 \\
$03 / 07 / 2010$ & 16.00 & 3.15 & 3 months & 2.06 \\
$15 / 12 / 2012$ & 10.80 & 2.00 & 3 months & 0.24 \\
$15 / 12 / 2011$ & 14.40 & 8.17 & 3 months & 1.13 \\
$23 / 10 / 2010$ & 6.00 & 0.50 & 3 months & 1.46 \\
$05 / 08 / 2011$ & 8.80 & 4.00 & 1 month & 1.44 \\
$25 / 03 / 2010$ & 6.40 & 5.00 & 1 month & 1.76 \\
\hline
\end{tabular}

Table 2. Characteristics of the rainfall events and corresponding evaluation indicators depending on the initial state of substrate saturation 


\section{3-3 Methodological framework}

By using Multi-Hydro and its green roof module on the Loup catchment, the aim of the study is to assess:

- The general impact of green roof on hydrological performances at the catchment scale

- The influence of initial condition

- The influence of green roofing spatial distribution

- The influence of precipitation spatial distribution

The general impact of green roof has been assessed by carrying out Multi-Hydro for the 16 rainfall events resulting from rain gauge. A comparison has been made between the current situation (industrial buildings are covered by impervious roofs) and a green roofing scenario (all industrial buildings are covered by $3 \mathrm{~cm}$ thick green roofs as those simulated by the model). The results obtained have been assessed by two indicators representing the reduction in terms of runoff volume $(\Delta V)$ and peak discharge $(\Delta Q p)$ :

$$
\begin{aligned}
& \Delta Q p(\%)=\frac{\left(Q p_{-} i m p-Q p_{-} g r\right)}{Q p_{-} i m p} \times 100 \\
& \Delta V(\%)=\frac{\left(V_{-} i m p-V_{-} g r\right)}{V_{-} i m p} \times 100
\end{aligned}
$$

Where $Q p \_i m p$ and $V \_i m p$ refer to peak discharge and runoff volume computed for the impervious situation whereas $Q p \_g r$ and $V \_g r$ correspond to those computed for the different green roofing scenarios.

To assess the influence of initial condition, three values of initial state of saturation have been applied uniformly in space: 10,30 and $50 \%$.

To assess the influence of green roofs' location, 3 different green roofing scenarios (covering one third of the industrial roofs) have been considered. Scenario 1 corresponds to the green roofing of the west side of the catchment, scenario 2 and 3 to the green roofing of the center and the east side of the catchment respectively. Initial saturation is fixed to $10 \%$ (favourable case) to better see the related impacts.

To assess the influence of spatial distribution of precipitation, the ensemble of 50 downscaled rainfall fields has been applied. For each downscaled field, responses to current (impervious) and green roofing configurations have been analyzed and compared.

\section{4-PRESENTATION OF THE RESULTS}

\section{4-1 General performances of green roof}

It has to be noticed first that results are less pronounced than those usually observed at the building scale because they depend on the green roofing area (34\% of the catchment area). Nevertheless, green roof appears to significantly impact urban runoff in terms of peak discharge and runoff volume depending on precipitation and the initial state of the substrate saturation (see Table 3). These reductions can reach around $70 \%$ for the more favourable cases (the smallest events with a low initial saturation). It is due to pervious areas and initial losses on impervious ones that make roof areas as a significant contributor to the runoff. 
For some moderate saturation conditions ( $\mathrm{IS}=30 \%$ ), volume runoff reduction is almost always higher than $10 \%$ and clearly related to the return period characterizing the rainfall event. For common events (return period strictly lower than 1 year), the implementation of green roof provides a retention of at least $20 \%$ of the runoff volume in most of the cases. In comparison, peak discharge reduction appears to be less pronounced and more related to the temporal distribution of precipitation. Indeed, this reduction can be higher than $10 \%$ for a large range of situations: low and moderate rainfall accumulation or intensity. When the event is composed of several rainfall peaks, green roof is able to store the first $\mathrm{mm}$ of precipitation and attenuate the corresponding first peak discharges. Nevertheless, the following peaks remain almost unchanged because substrate is saturated and has no time to recover its storage capacity. Note that green roof is usually able to impact on the highest peak of rainfall (as depicted in Figure 3 (a)). In very few cases, the implementation of green roof can produce higher peak discharge than the impervious situation (See also Section 4-4). In such situations characterized by an event with two rainfall peaks, the fast response of the saturated substrate generated by the "second peak" of the rainfall coincides with the slow response of the green roof produced by the initial portion of the rainfall event (concomitance situation).

\section{4-2 The influence of initial condition on green roof performances}

Results confirm that antecedent soil moisture condition is a key-factor influencing the hydrological response of green roof: more saturated is the substrate, less significant is its impact. In dry condition, the reduction in runoff volume is at least of $15 \%$ and reaches more than $30 \%$ for every current event characterized by a return period lower than one year. The reduction in peak discharge is more variable but can be higher than $80 \%$ for the more current events (monthly as illustrated Figure 3 (c)). When substrate is saturated (IS=50\%), the impact of green roof is still effective (both reductions are respectively around $30 \%$ and $10 \%$ ).
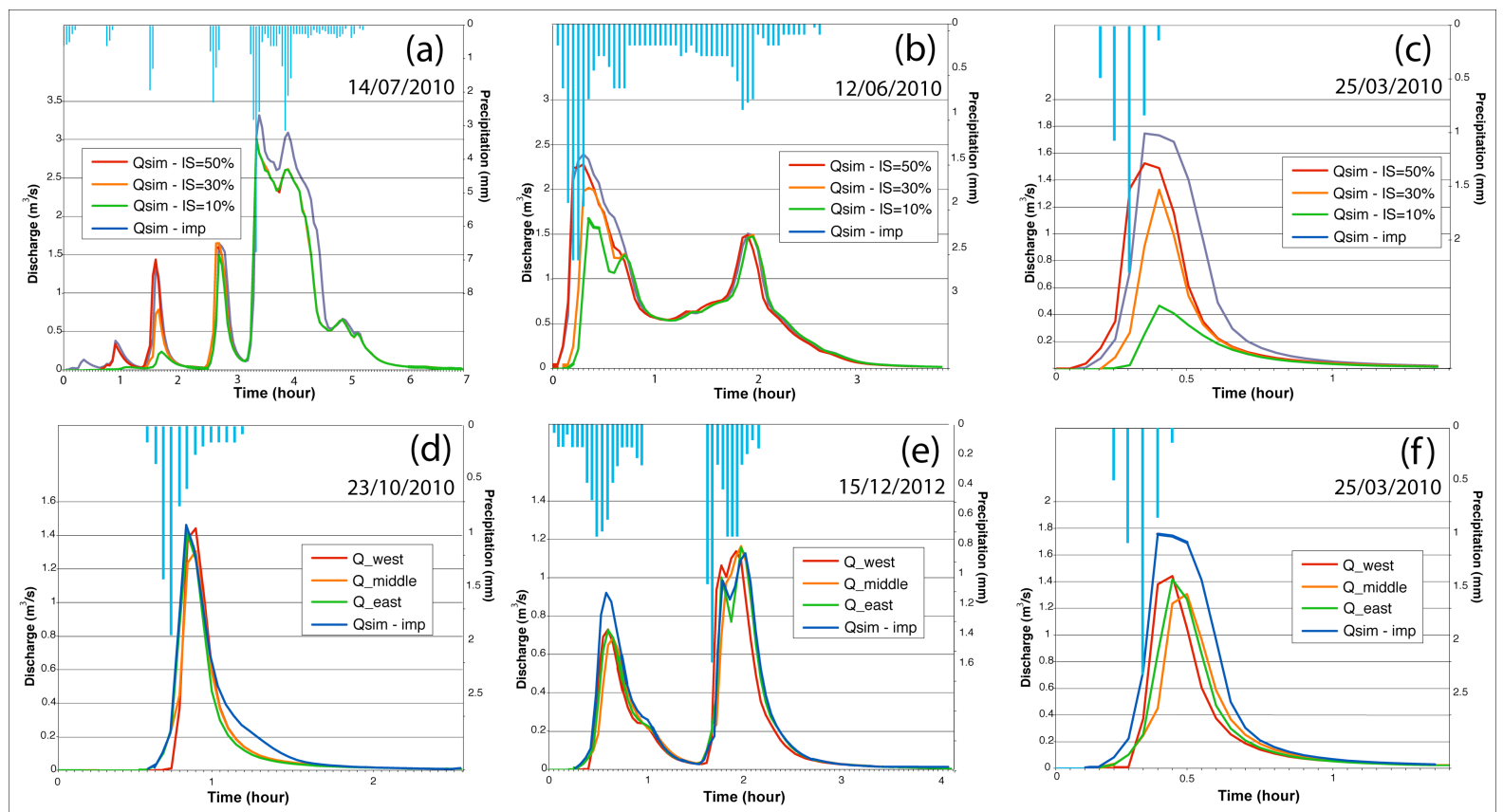

Figure 3. Simulated discharge for the current impervious situation (Qsim-Imp) and comparison with: 3 different initial condition scenarios (Qsim-IS $=50 \%$, Qsim-IS $=30 \%$ and Qsim-IS $=10 \%$ ) at the top, and 3 different green roofing scenarios (west, middle and east) at the bottom. 
The difference between a $10 \%$ and a $50 \%$ initial saturation represents a storage capacity of about $6 \mathrm{~mm}$ for this $3 \mathrm{~cm}$ thickness substrate. It seems enough to significantly reduce the consequences of a wide range of rainfall events. For this reason, the implementation of green roof of this thickness of substrate is more efficient for standard and short rainfall events than for long extreme events for which the substrate could be rapidly saturated. In consequences, green roof should be more adapted to reduce the impacts of summer rainfall event than winter ones. Moreover, as evapotranspiration is higher in summer, the probability to have low initial state of the substrate saturation is generally higher.

\section{4-3 The influence of green roofing spatial distribution on performances}

First of all, is has to be mentioned that green roof performances are clearly lower than those noticed in the previous section (see Table 3 ). As only one third of the green roofing potential is effectively covered by green roof, runoff reduction is attenuated. As mentioned above, large scale implementation of green roof is needed to significantly reduce overflows in the drainage network. Here, for each scenario, only around $10 \%$ of the catchment area is covered by green roofs, which is not enough to significantly act on moderate and severe long rainfall events. For this reason, only results computed for common events (return period less than 3 months) are depicted in Figure 3 (bottom).

It is worth noting that green roof spatial distribution has little influence on the Loup catchment response. For the two lowest events (25/03/2010 and 23/10/2010), peak discharge rising seems to be delayed by one time step between West and East green roofing scenarios: closer to the outlet, faster to answer. In the West green roofing configuration, green roof slows down discharge, which is now synchronized with downstream contributions. These events represent another interesting example of a concomitance situation. Finally, green roof spatial distribution has no influence on volume reduction.

\begin{tabular}{|c|c|c|c|c|c|c|c|c|c|c|c|c|}
\hline \multirow[b]{3}{*}{ Date } & \multicolumn{6}{|c|}{ Initial condition scenarios } & \multicolumn{6}{|c|}{ Green roofing scenarios } \\
\hline & \multicolumn{2}{|c|}{$\mathrm{IS}=50 \%$} & \multicolumn{2}{|c|}{$\mathrm{IS}=30 \%$} & \multicolumn{2}{|c|}{$\mathrm{IS}=10 \%$} & \multicolumn{2}{|c|}{ West } & \multicolumn{2}{|c|}{ Middle } & \multicolumn{2}{|c|}{ East } \\
\hline & $\begin{array}{l}\Delta V \\
(\%)\end{array}$ & $\begin{array}{c}\Delta Q p \\
(\%)\end{array}$ & $\begin{array}{l}\Delta V \\
(\%)\end{array}$ & $\begin{array}{c}\Delta Q p \\
(\%)\end{array}$ & $\begin{array}{l}\Delta V \\
(\%)\end{array}$ & $\begin{array}{l}\Delta Q p \\
(\%)\end{array}$ & $\begin{array}{l}\Delta V \\
(\%)\end{array}$ & $\begin{array}{c}\Delta Q p \\
(\%)\end{array}$ & $\begin{array}{l}\Delta V \\
(\%)\end{array}$ & $\begin{array}{c}\Delta Q p \\
(\%)\end{array}$ & $\begin{array}{l}\Delta V \\
(\%)\end{array}$ & $\begin{array}{c}\triangle Q p \\
(\%)\end{array}$ \\
\hline $14 / 07 / 2010$ & 11.0 & 9.3 & 15.3 & 8.8 & 19.9 & 9.2 & 13.2 & 15.5 & 13.2 & 7.9 & 13.2 & 15.6 \\
\hline $12 / 07 / 2010$ & 2.5 & 2.6 & 8.6 & 3.7 & 14.5 & 6.5 & 7.9 & 1.8 & 7.4 & 4.8 & 7.8 & 4.9 \\
\hline $12 / 06 / 2010$ & 4.6 & 4.7 & 12.3 & 15.7 & 20.1 & 30.1 & 9.8 & 11.6 & 9.4 & 15.4 & 9.6 & 14.2 \\
\hline $05 / 06 / 2011$ & 2.2 & 1.1 & 12.1 & 5.7 & 18.9 & 12.2 & 3.5 & 2.7 & 3.4 & 2.2 & 3.4 & 3.5 \\
\hline $03 / 06 / 2012$ & 10.2 & 5.8 & 18.4 & 6.2 & 26.5 & 13.2 & 13.3 & 6.8 & 13.2 & 6.6 & 13.2 & 7.8 \\
\hline $26 / 08 / 2011$ & 1.8 & -0.9 & 7.6 & 3.7 & 17.1 & 9.6 & 3.2 & 7.6 & 3.1 & 5.6 & 3.1 & 7.6 \\
\hline $21 / 06 / 2012$ & 3.2 & 2.8 & 15.1 & 10.6 & 34.5 & 29.0 & 11.9 & 8.8 & 11.6 & 10.5 & 11.6 & 7.4 \\
\hline $19 / 05 / 2012$ & 3.5 & -3.9 & 17.9 & -2.6 & 35.9 & 6.1 & 9.6 & 1.3 & 9.4 & 0.2 & 9.5 & -0.2 \\
\hline $03 / 11 / 2012$ & 6.9 & 2.9 & 20.4 & 3.2 & 33.9 & 3.0 & 11.5 & 4.9 & 11.3 & 4.7 & 11.5 & 2.7 \\
\hline $22 / 07 / 2011$ & 14.1 & 36.7 & 33.2 & 50.3 & 62.4 & 85.9 & 24.8 & 42.7 & 24.5 & 45.0 & 23.7 & 36.4 \\
\hline 03/07/2010 & 7.5 & 1.2 & 21.3 & 21.1 & 30.1 & 34.5 & 12.4 & 7.6 & 12.3 & 7.2 & 12.5 & 9.2 \\
\hline $15 / 12 / 2012$ & 2.7 & -12.1 & 20.0 & -11.8 & 42.9 & 0.3 & 5.1 & 0.0 & 4.9 & 0.0 & 4.9 & 0.0 \\
\hline $15 / 12 / 2011$ & 4.8 & -0.4 & 19.8 & 1.7 & 34.9 & 1.7 & 9.0 & -1.2 & 9.0 & 0.0 & 9.1 & 1.3 \\
\hline $23 / 10 / 2010$ & 26.5 & 24.2 & 56.3 & 69.4 & 71.7 & 81.5 & 32.1 & 31.4 & 32.0 & 34.7 & 31.7 & 32.5 \\
\hline 05/08/2011 & 9.1 & 15.6 & 28.7 & 14.8 & 50.6 & 64.7 & 18.3 & 24.1 & 18.1 & 26.7 & 17.4 & 29.8 \\
\hline $25 / 03 / 2010$ & 25.4 & 12.6 & 48.1 & 23.9 & 70.9 & 73.0 & 34.6 & 17.9 & 34.2 & 25.6 & 33.2 & 19.4 \\
\hline
\end{tabular}

Table 3. Evaluation indicators computed for every rainfall event considering different initial states of substrate saturation (left) and different green roofing scenarios (right). 
For the 2009 radar common event (similar to the 25/03/2010 event presented in Figure 3), catchment response can significantly be modified depending on the spatial variability of rainfall distribution (see Figure 4). Peak discharge for the impervious scenario varies between 0.10 and $0.15 \mathrm{~m}^{3} / \mathrm{s}$, and between 0.06 and $0.11 \mathrm{~m}^{3} / \mathrm{s}$ for the green roofing one respectively.

As expected by considering the return period of the studied event ( 1 month), performances of green roof are very significant. Average runoff volume and peak discharge decreases are respectively about $36 \%$ and $35 \%$. Green roof implementation contributes to significantly reduce the stormwater quantity reaching the sewage network. $\triangle Q p$ (characterized by a standard deviation of $8 \%$ ) ranges between $10 \%$ and $56 \%$ depending on the downscaled scenario. Despite a similar return period, note that performances were better for the 25/03/2010 event (Figure 3 (c)), which confirm that green roof seems to be particularly efficient for very short (but sometimes intense) rainfalls.

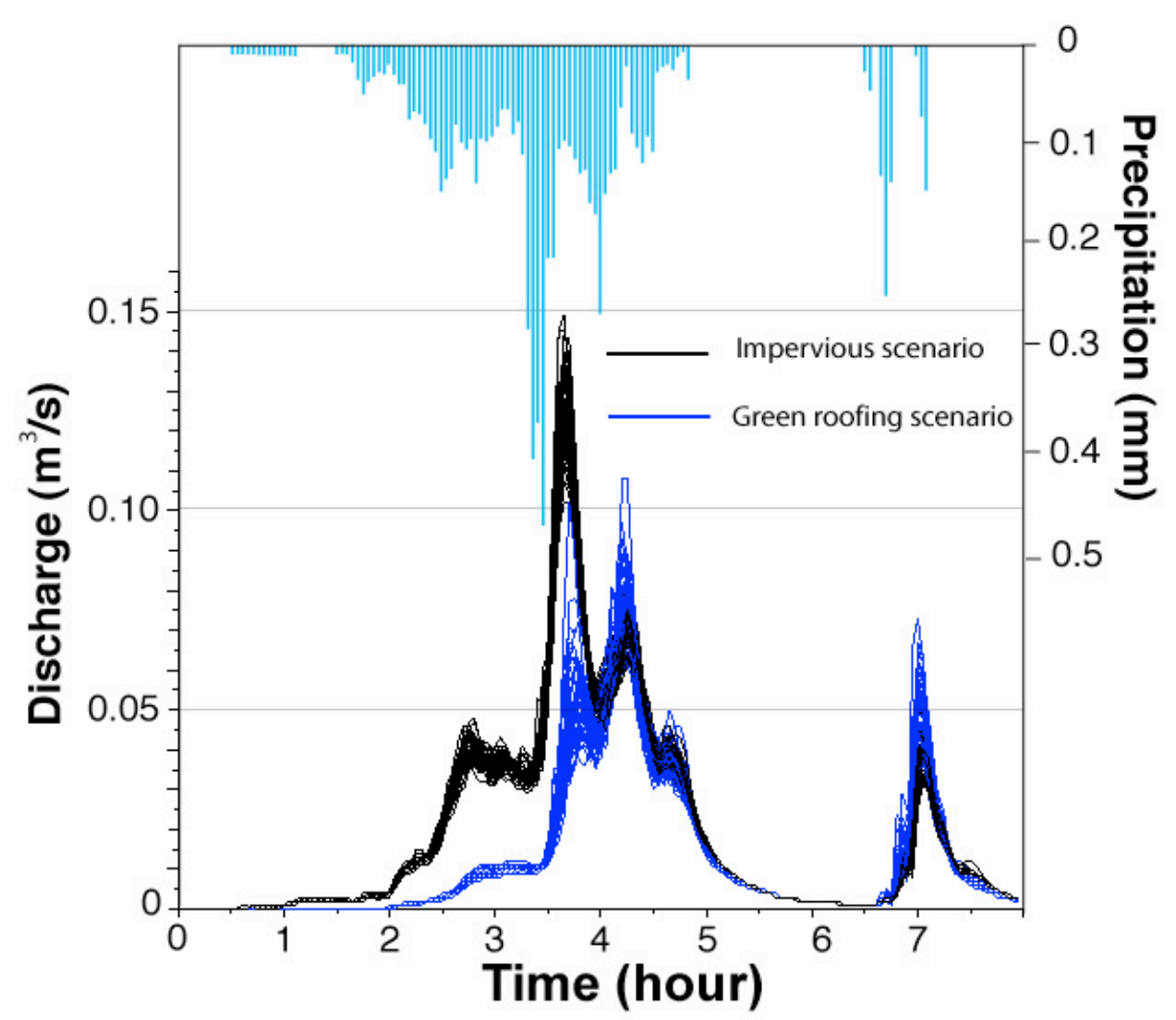

Figure 4. Simulated discharge computed for impervious and green roof scenarios and using an ensemble of 50 downscaled rainfall field for the 2009 radar event.

These satisfactory results are most of all concentrated on the first rainfall peak as illustrated by Figure 4 . Here, catchment response to the main rainfall intensity is clearly attenuated but likewise dispersed (standard deviation of $0.011 \mathrm{~m}^{3} / \mathrm{s}$ in both cases). Conversely, the response to the second rainfall peak is systematically increased by green roofs (from 0 to $33 \%$ with an average value of $10 \%$ ). The range of simulated values is also more dispersed (standard deviation of $0.004 \mathrm{~m}^{3} / \mathrm{s}$ in impervious situation, 0.008 for green roof scenario respectively), increasing the sensitivity of the catchment regarding precipitation. First peak decreases and second peak increases are quite correlated (correlation coefficient of 0.62), meaning attenuation of the first one seems to cause gain of the second one. In this case, the substrate 
stores precipitation during the first part of the event, before releasing it simultaneously with the second rainfall peak.

As already mentioned in Sections 4.1 and 4.2, this represents a new example of a concomitance situation. These results are related to both the spatio-temporal distribution of precipitation and the specific configuration of the studied catchment (especially on the catchment geometry and land cover, and the sewage network arrangement). The superposition in space and time of responses from impervious and a green roofed areas to a complex rainfall event (composed by several rainfall peaks for example) can generate a peak discharge higher than that produced by the current (impervious) situation.

\section{5- CONCLUSION}

This paper discusses the first study of hydrological impacts of green roofs regarding the spatial distribution of precipitation during several rainfall events by using a fully distributed model implemented on a real urban catchment. A conceptual green roof module has been integrated into the 'event-adapted' version of Multi-Hydro distributed rainfall-runoff model especially devoted to urban environment. Adjusted by using monitored data, it has been applied on a small urban catchment close to Paris, where $34 \%$ of the area could theoretically be covered by green roofs.

These first results, that should be confirmed in the future, illustrate that green roof implementation can significantly reduce urban runoff in terms of peak discharge and volume depending on rainfall event characteristics and the initial state of the substrate saturation. The representation of these initial conditions by an input parameter (Init) makes easy the computation of hydrological impacts in an optimistic/pessimistic perspective. This is particularly useful for a rapid operational analysis. Note that these reductions can reach more than $70 \%$ in dry condition for monthly events. It could be enough to avoid some sewage overflows situations occurring at this frequency in the Paris area. It is particularly efficient for very short (but intense) rainfalls that are expected to occur more often in Paris area due to climate change (Hoang et al. 2012).

Spatial distributions of green roof and precipitation have also been considered. Concerning the first, it appears that the total amount of green roof areas is more important than their locations. When green roofs are only implemented on one third of the roofs, stormwater reduction is significantly attenuated and only visible for the most common events. This confirms that a large scale implementation is needed to significantly (and systematically) reduce overflows in the drainage network. It seems also wiser to implement green roof in the upstream part of the catchment to delay runoff, rather than downstream where concomitance situations can occur.

Nevertheless concomitance situations have to be carefully considered. As illustrated with the Loup catchment, depending on the considered downscaled rainfall scenario, the combination of catchment configuration and precipitation can produce higher peak discharge than that produced in the current situation (impervious roofs). The layout of impervious and greened areas makes complex interaction with high heterogeneous precipitation as it can occur in convective situation. Nevertheless, this example also shows that the most significant peak discharge has always been significantly reduced whatever the downscaled scenario. 
These previous examples illustrate the interest in having a distributed rainfall-runoff model able to consider the wide complexity of an urban environment. By its distributed structure, Multi-Hydro is able to take into account both landcover (to study possible concomitance situations) and precipitation spatial distribution (to consider the associated uncertainty) in impact studies at small scales (quarter or urban project development). It makes it possible to assess the possible contribution of Sustainable Urban Drainage Systems (SUDS) implemented at the parcel scale to reduce the potential impact of new and existing developments with respect to stormwater issues. For now the development of the MultiHydro platform as an operational tool is still in progress. Use of a conceptual green roof module with the full version of Multi-Hydro remains a highly attractive perspective to reduce the computation time, in particular for using it as the catchment-scale operational tool. The first obtained results clearly supports further development in this direction.

The implementation of a more physical model to represent green roof behaviour is also an interesting track development. It will allow testing of the impact of various green roof configurations differentiating by their substrate porosity and thickness for instance. Indeed, for a question of cost and ease of implementation, a thin substrate of $3 \mathrm{~cm}$ was used here. The use of a thicker substrate should improve its retention capacity. Moreover, by implementing the full version of Multi-Hydro at a roof scale, it should be possible to assess green roof performances on a larger period than the event one, and to better estimate the initial state of the substrate saturation.

Results presented above could appear optimistic because it has been assumed that green roofs have been widely implemented. Combined with other SUDS, green roof could participate in significantly reducing the quantity of water flowing into the sewage network during storm events. For this reason, this work represents a good opportunity to promote the dissemination of green roof - such as other blue and green infrastructures (like bioretention swale, ponds, rain garden) - in new urban developments and for retrofitting in already existing urban areas. In addition to thermal and environmental benefits, these infrastructures can be valuable from an urban water management point of view.

\section{ACKNOWLEDGEMENT}

This work is part of the Climate-KIC funded Blue Green Dream project (http://bgd.org.uk/) that promotes the implementation of blue and green infrastructures to maximize ecosystem services and increase resilience to climate change. Authors would like to thank Jean-Baptiste Abbes who initially implemented the Multi-Hydro on the Loup catchment. The authors also acknowledge Météo-France for providing the radar rainfall estimates in an easily exploitable format, Water Direction of the Seine-Saint-Denis County for providing additional rainfall data and CEREMA for providing monitored data from their experimental green roofs. Finally, the authors thank anonymous referees for their very useful comments and suggestions.

\section{REFERENCES}

Berndtsson, J.C., 2010. Green roof performance towards management of runoff water quantity and quality: A review. Ecological Engineering, 36(4): 351-360.

Carson, T.B., Marasco, D.E., Culligan, P.J., McGillis, W.R., 2013. Hydrological performance of extensive green roofs in New York City: observations and multi-year modeling of $\hat{A}$ three full-scale systems. Environ. Res. Lett. 8 (2), 24- 36.

Carter, T. and Jackson C. R. 2007. Vegetated roofs for stormwater management at multiple spatial scales. Landscape and urban planning, 80, 84-94. 
El Tabach, E., Tchiguirinskaia, I., Mahmood, O., and Schertzer, D., 2009. Multi-Hydro: a spatially distributed numerical model to assess and manage runoff processes in periurban watersheds. In: E. Pasche, N. Evelpidou, C. Zevenbergen, R. Ashley and S. Garvin, eds. Final Conference of the COST Action C22, Road map towards flood resilient Urban Environment, Paris, France. Hamburger Wasserbau-Schriften.

Fassman-Beck, E., Voyde, E., Simcock, R., Hong, Y.S., 2013. 4 Living roofs in 3 locations: does configuration affect runoff mitigation? Journal of Hydrology. 490, 11-20.

Giangola-Murzyn, A., 2014. Modélisation et paramétrisation hydrologique de la ville, résilience aux inondations, $\mathrm{PhD}$ thesis, Université Paris-Est, $260 \mathrm{pp}$.

Gires, A., Tchiguirinskaia, I., Schertzer, D., and Lovejoy, S., 2012. Multifractal analysis of an urban hydrological model on a Seine-Saint-Denis study case. Urban Water Journal, 10 (3), 195-208.

Gires, A., Giangola-Murzyn, A., Abbes, J.B., Tchiguirinskaia, I., Schertzer, D., and Lovejoy, S., 2014. Impacts of small scale rainfall variability in urban areas: a case study with $1 \mathrm{D}$ and $1 \mathrm{D} / 2 \mathrm{D}$ hydrological models in a multifractal framework. Urban Water Journal. DOI: 10.1080/1573062X.2014.923917

Gromaire, M.-C., D., R., Seidl, M., Berthier, E., Saad, M. and de Gouvello, B., 2013. Incidence of extensive green roof structures on the quantity and the quality of runoff waters, NOVATECH, Lyon (France), 10 pp.

Hilten, R.N., Lawrence, T.M. and Tollner, E.W., 2008. Modeling stormwater runoff from green roofs with HYDRUS-1D. Journal of Hydrology, 358(3-4): 288-293.

Hoang, C.T., Tchiguirinskaia, I., Schertzer, D., Arnaud, P., Lavabre, J., Lovejoy, S., 2012. Assessing the high frequency quality of long rainfall series. Journal of Hydrology, 3538-439: 39-51.

Locatelli, L., Mark, O., Mikkelsen, P.S., Arnbjerg-Nielsen, K., Bergen Jensen, M., Binning, P.J., 2014. Modelling of green roof hydrological performance for urban drainage applications, Journal of Hydrology, $519: 3237-3248$

Mills, P.C., and Healy, R.W., 1993. Water and tritium movement through the unsaturated zone at a low-level radioactive-waste disposal site near Sheffield, Illinois, 1981-85: U.S. Geological Survey Water-Supply Paper 2386, 72 p.

Palla, A., Berreta., C, Lanza, L.G.and La Barbera, P. 2008. Modelling storm water control operated green roofs at the urban catchment scale. 11th International Conference on Urban Drainage, Edinburgh, (Scotland).

Palla, A., Gnecco I., Lanza L.G. 2009. Unsaturated 2D modelling of subsurface water flow in the coarse-grained porous matrix of a green roof. Journal of Hydrology, 379, 193-204

Rossman, L.A., 2004. Storm water management model User's manual version 5.0, Water Supply and Water Resources Division, National Risk Management Research Laboratory, Cincinnati (USA).

Schertzer, D. and Lovejoy, S., 1987. Physical modelling and analysis of rain and clouds by anisotropic scaling and multiplicative processes. Journal of Geophysical Research, 92 (D8), 9693-9714.

Schertzer, D. and Lovejoy, S., 2011. Multifractals, Generalized Scale Invariance and Complexity in Geophysics. Inter- national Journal of Bifurcation and Chaos, 21 (12), $3417-3456$.

Simmons, M.T., Gardiner, B., Windhager, S., Tinsley, J., 2008. Green roofs are not created equal: the hydrologic and thermal performance of six different extensive green roofs and reflective and non-reflective roofs in a sub-tropical climate. Urban Ecosyst. 11 (4), 339-348.

Stovin, V., Vesuviano, G. and Kasmin, H., 2012. The hydrological performance of a green roof test bed under UK climatic conditions. Journal of Hydrology, 414-415: 148-161. 
Stovin V1, Poë S, Berretta C. 2013. A modelling study of long term green roof retention performance. Journal of Environmental Management, 131: 206-215

Velleux, M.L., England, J.F., and Julien, P.Y., 2011. TREX watershed modelling framework user's manual: model theory and description. Fort Collins, CO: Department of Civil Engineering, Colorado State University.

Versini, P.-A, Ramier, D., Berthier, E. and de Gouvello, B., 2015a. Assessment of the hydrological impacts of green roof: from roof scale to basin scale. Journal of hydrology, 524: 562-575.

Versini, P.A., Jouve, P., Ramier, D., Berthier, E. and de Gouvello, B., 2015b. Use of green roofs to solve storm water issues at the basin scale - Study in the Hauts-de-Seine county (France). Urban Water Journal. http://dx.doi.org/10.1080/1573062X.2014.993993

Yilmaz, D., Sabre, M., Lassabatère, L., Dal, M., and Rodriguez, F., 2016. Storm water retention and actual evapotranspiration performances of experimental green roofs in French oceanic climate. European Journal of Environmental and Civil Engineering, 20(3): 344-362 